\title{
Making Refugees Work? Individualized Work Strategies in the Swedish Refugee Settlement Program'
}

I Eva Wikström²

PhD, Department of Social Work, Umeå University, Sweden

I Petra Ahnlund

PhD, Department of Social Work, Umeå University, Sweden

\begin{abstract}
In Sweden and elsewhere, work strategies have gained greater significance in social policy, and now also in settlement programs for refugees. This article addresses the level of practice of the refugee settlement program in Sweden, which previously emphasized 'support' and 'social responsibility', but now emphasizes 'activation' and 'individual responsibility'. Through an analysis of interviews and individual action plans, we investigate how activation is put into practice in the work activities of refugee settlement and how employment officials and refugees articulate and experience the role that activation plays in refugees' integration processes. The conclusion drawn is that activation is a central feature, but it involves conditionalizing elements that are used as the means to emphasize 'work' as the route to integration and to keep the 'less employable' refugees activated. The activation techniques applied require refugees to demonstrate that they are taking responsibility for their integration process and for increasing their employability.
\end{abstract}

\section{KEY WORDS}

Refugee settlement / work strategies / responsibilization / unemployment / individual action plans

\section{Introduction}

'Work strategy' has been an important concept in Swedish social policy for decades, but it gained reinforced significance from 2006 onwards after the right-wing government came into power (Regeringsförklaringen 2006). The return of the Social-Democratic Party into governance in 2014 meant contrary to what was might expected, a continuation of the political emphasis on placing work and activation at the center of tackling many social conditions associated with 'social risks' such as poverty, sickness, long-term unemployment, and now also as a salient means to speed up refugees' integration process (Regeringsförklaringen 2014). It is claimed that the contemporary version of 'work strategy' has been discursively transferred and in practice adopted to a growing number of policy areas (Hobbins 2016; Peeters 2013; Trnka \& Trundle 2014; Vesterberg 2015). In a previous issue of this journal, Hobbins (2016) provides an illustrative example of how the discourses on an individualized work strategy permeate Swedish programs directed to long-term unemployed youth. The implementation of work strategies rests

\footnotetext{
${ }^{1}$ You can find this text and its DOI at https://tidsskrift.dk/njwls/index.

${ }^{2}$ Corresponding author: Eva Wikström, (eva.wikstrom@umu.se).
} 
on a strong belief that all individuals are able to work to some extent and that everyone benefits from sharing society's workload by 'doing their bit' and being responsible for their own upkeep (Hobbins 2016; Johansson \& Møller 2009). Studies have shown that in many welfare-state policy areas, a gradual shift has occurred in the use of measures emphasizing individual responsibility for improving one's life-situation and for demonstrating the ability to live up to desirable norms on acceptable behaviors and lifestyles (Douglas 1994; Ericson et al. 2000; Garland 2001; Mik-Meyer \& Villardsen 2012; Rose 1996). Thus, individualized 'work strategy measures' for the unemployed often involve conditionalizing elements such as expectations on the individual to partake in suggested programs and to accept job offers, thus demonstrating a good work ethic and the intention to take responsibility as a social contributor (Clarke 2005; Dean 2007; Peeters 2013). However, in international comparisons, Sweden is well known for its generous welfare-state provision of support to newly arrived refugees, including language training, housing, health care, civic instructions, and measures to prepare for working life, for a 2-year period of time (Borevi 2013; Djuve \& Kavli 2007; Fernandes 2013). In Sweden, as well as in other Nordic countries such as Denmark and Norway (Fernandes $2013,2015)$, participation in the refugee-settlement programs is formulated in legislation as a right, meaning that the target group has the right to the various measures and payments provided through the introduction benefit (Djuve \& Kavli 2007; Fernandes 2015). At present, however, the Swedish settlement program for refugees (SFS 2010:197) represents a break from the previous program (SFS 1992:1068) and has been described as a shift away from an introduction program with an emphasis on 'support' toward a program stressing 'fast employment' and activation (Fernandes 2015; Larsson 2015; Qvist 2012). Regarding refugees' experiences of flight, persecution, and war, research shows that there is great variation in refugees' readiness to enter into employment and to be able to participate in all aspects of social life (Slewa-Younan et al. 2015). This implies that in planning and providing support to refugees, the ability to work and to benefit from partaking in various work-training programs might vary to a great extent (Lecerof et al. 2015). The results from a limited number of studies on the present Swedish refugee settlement program (Fernandes 2015; Qvist 2012) have mostly stated that there is a strong focus on work in policy texts, and only a few studies have looked into how the work focus is put into practice (Larsson 2015; Vesterberg 2013). There are no previous studies on how activation strategies function in detail, what they are used for, or how they are experienced by refugees. Therefore, the aim of this article is to investigate in what ways work strategies influence the activities in which refugees take part and how employment officials and refugees articulate and experience the role that activation plays in refugees' integration processes.

Policy programs that are in general developed in the name of activity have in many cases led to ambiguous outcomes and to discord between conditionality and autonomy (Djuve 2011; Vesterberg 2013, 2015). While some studies indicate that programs that emphasize self-governance means boosting individuals' motivation and willpower (Heidenreich \& Aurich-Beerheide 2014), there are other studies indicating that programs emphasizing individual responsibility presume employability and agency, which therefore might be beneficial for those who have the resources that the labor market demands (Dingeldey 2007). One of the few studies on work strategies in the Swedish refugee settlement program showed that public employment services [PES] officials have to use various strategies to live up to the steering mechanisms in the policy and have to

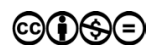


adapt the compulsory activation measures to the refugee clients' shifting preparedness to participate in activation on a full-time basis (Larsson 2015). One adaptive strategy used by the officials is to fill up the establishment plans of the newly arrived immigrants with what Larsson calls 'empty activities' (p. 315-316). A reason for these kinds of strategies is that officials are trying to live up to the requirements of the policy to enable 'full time activation' and thus meet the expectations that are imposed upon them (Larsson 2015 , p. 316). The results from Larsson's study imply that work-strategies applied in a performance-based and conditionalized system might lead to the provision of meaningless activities for the sake of activation, 'filling the numbers', and meeting the eligibility criteria for receiving benefits.

The meta-theoretical background to the present article is that ideas and practices travel between organization and institutions (Czarniawska-Joerges \& Sevón 2005). In the case of 'work strategies' in refugee settlement, it is possible to assume that ideas and practices focusing on 'employment' and 'activation' have travelled and been translated from the field of labor market policy to the field of refugee integration policy. However, it is questionable as to whether practices such as 'activation' ever needed to be translated to fit other organizations or other public actors in the first place because the institutional shift of the refugee-integration program that took place in 2010 meant that the program became situated within the realm of the PES. Thus, the process of translation more likely concerns how 'work focus' is transferred to a 'new' group of people, to refugees, rather than being applied to the unemployed in general.

\section{Background to political ideas on work strategies in Swedish refugee settlement policy}

In Sweden, the granting of refugee status involves rights for the newly arrived to receive state-provided financial and practical support for 2 years. The aim of settlement programs for refugees in general is to facilitate the integration of the refugees into the receiving nation, and these programs often involve language courses, labor-market planning, and vocational training in order for newly arrived individuals to become self-providing and settled locally. The previous Swedish introduction program for refugees was, in a Nordic comparison, described as having higher levels of benefits, fewer compulsory activities, and a weaker emphasis on sanctions-backed activation strategies compared to other Nordic nations such as Denmark and Norway (Brochman \& Hagelund 2011; Djuve \& Kavli 2007). Prior to the launching of this earlier version of the settlement program for refugees (1997/98:16), it was stated that local governments had the main responsibility to flexibly respond to the multiple needs of the refugees (Government bill 1997/98:16, p. 75). Discussions about the need for changing direction in the refugee-settlement program started to turn up in the late 1990s and early 2000s (Borevi 2013; Brekke \& Borchgrevink 2007; Djuve 2011), and criticism was often heard that the services being provided did not offer the necessary incentives to push refugees into the labor market and to break them from 'welfare dependency' (Qvist 2012: 16). Arguments for policy changes were also based on studies showing ethnic employment gaps in the Swedish workforce as evidenced by low incomes, high dependency on social assistance, and poor Swedish language skills among some groups of refugees (Folkpartiet 2004, 2008; SOU 2006:79). Of concern for Swedish policymakers was that 
the settlement needed to become more focused on labor-market integration and on promoting an active and self-reliant refugee (Government bill 2009/10:60, p. 39). The urge to change policy direction can be seen in the use of certain words in the labels of the government texts, for example, From caring to responsibility - effective establishment services for newly arrived immigrants (2009/10:60, p 24). Prior to the launching of the 'new' settlement policy, there were several arguments about creating motivational incentives for new arrivals to participate in integration activities and how authorities needed to take a step back but still play a role in putting demands on the refugee and in providing incentives for them to integrate into Swedish society (SOU 2008:58, p. 62). Put at center stage was the idea of the refugee as a worker and contributor with an emphasis on the duties of the refugee to participate and to accept the training placements and jobs that were offered (SFS 2010:197; SOU 2008:58). An institutional change to serve the purpose of 'work focus' was the transference of overall responsibility for the program from the municipalities to the PES. Examples of how these duties are practiced include the requirement for the refugee to start the program within 1 year after being settled locally, otherwise the right to participate expires, and the demand for full-time participation in the program, which is 8 hours per weekday, in order to receive the benefits (SFS 2009/10:60: 40; 2010:197). Individuals with less than 25\% work capacity are excluded from the 'establishment program' and instead apply for support from the social services. The public employment officers (EOs) are obligated to make an initial inquiry with the refugee with the aim of assessing the individual's ability to work. If officials find it necessary, they can advise the refugee to contact a health care center to have such an assessment made by medical experts.

\section{Swedish labor market policy}

Considering the presentation above, the adoption of 'work focus' in refugee settlement policy is without doubt linked to the changes in Swedish labor market policy (Fernandes 2015; Qvist 2012). Therefore, it is useful to give an overview of some changes in labor market policy that relate to individualized work strategies. Internationally, the Swedish model of labor market policy is associated with the social democratic regime's goal of full employment, investments in the labor force through comprehensive active and offensive labor market measures, and generous unemployment insurances (Bengtsson \& Berglund 2012; Esping-Andersen 1990). The 'offensive' work strategies applied in the "Swedish model" aimed to strengthen the resources of the unemployed, while from 1990s and onward, these gradually turned into more defensive work strategies (Torfing 1999). In the late 1990s, the emphasis on activation measures changed the discourses on labor market policy in Sweden from viewing unemployment as caused by 'lack of employment' to viewing unemployment foremost as individuals' 'lack of employability' (Bengtsson \& Berglund 2012; Garsten \& Jacobsson 2004; Johansson \& Møller 2009). It is argued that instead of increasing the competence of the labor force, the emphasis in labor market programs is on lowering the costs and making considerable changes in labor market insurance with tightened eligibility criteria and lowered levels of benefit (Bengtsson \& Berglund 2012). This is combined with a conditionalization of the activation strategies and benefits involved, putting the unemployed under pressure with sanctions and time limitations with the aim of creating incentives for the unemployed 
to choose work in preference to living on benefits (Barbier 2004; Johansson \& Møller 2004). A more disciplining character of labor market programs (Barbier 2004), together with a neoliberal notion of individual autonomy, is argued to have individualized the responsibilities for escaping unemployment (Hobbins 2016). From 2006 onwards, a marked intensification of the individualization in labor market policy is discernible along with increased emphasis on unemployed individuals working on themselves, for example, to improve their competences, capabilities, motivation, or work ethic (Hobbins 2016). Such an emphasis on individualized responsibility in refugee-settlement policies might be viewed as part of an empowerment ideology aiming to prevent the capacities and agencies of refugees from being tied up by institutional constraints and clientization processes (Fernandes 2015; Qvist 2012). However, it is also claimed that individualized responsibility is part of a general welfare-state retrenchment, leaving much of the responsibility for recovery and inclusion to the individual (Clarke 2005; Dean 2007; Garland 2001; Peeters 2013). As such, there is ambiguity as to whether the outcome of these new integration policies is a freeing of individual capacities (Eastmond 2011) or, on the contrary, if they lead to an abandonment of the individual and an exclusion of those with fewer resources and reduced capacities (Shutes 2011; Wiggan 2012).

\section{Activation and responsibilization}

Two concepts of relevance to illustrate the policy trend of individualized work strategies are activation and responsibilization, which have also proven to be of importance in analyzing our empirical data. The Scandinavian countries are often referred to as 'the active corner in Europe' (Bengtsson 2014; LØdemel \& Trickey 2001). Active labor market policies in Scandinavia have for a long time had an important role in welfare policies, but since the 1990s, these have changed from human capital-strengthening measures to more compulsory 'work first' initiatives based on the principle that 'everyone with at least some work capacity should work' (Bengtsson 2014; Handler 2003; Lødemel \& Trickey 2001). Activation is best understood as an umbrella concept that signifies substantial changes in social policies aiming at promoting the more or less obligatory participation in labor (Bengtsson 2014, p. 55). Activation is discussed either regarding its 'enabling elements', that is, as something strengthening and empowering citizenship or on the contrary in terms of its demanding or conditional elements, also referred to as the 'work first' approach (Dean 2007; Handler 2003; Peck \& Theodore 2000). The enabling activation practices target the strengthening of human capacity for the purposes of long-term employment. Applied this way, the policy consists of improving the human capital of the unemployed through education, assisted job searches, short-term work preparations, and incentives to participate in work programs (Bengtsson 2014; Peck \& Theodore 2000; Torfing 1999).

The work-first approach is, in contrast, about moving people from welfare to work as soon as possible and involves strategies that are more or less conditionally produced through benefit cuts, tightening of eligibility criteria, and mandatory work programs in order to move people out of joblessness. Moreover, the work-first approach is often thought of as anchored on ideas of 'welfare traps', and it follows the principle that any job is better than no job at all (Bengtsson 2014, p. 56; cf. Standing 2011). Several scholars argue that activation policies have forcefully redistributed the risks associated 
with job-market instability from the state to the unemployed (Peck \& Theodore 2000; cf. Newman 2011). Thus, the focus is on what individuals can do to improve their own situation, for example, in relation to health and work, rather than focusing on redistributing risks by means of a public insurance system. In this discourse, the 'responsible citizen' refers to the individual who works on themself, that is, they seek out education, job opportunities, and behaviors that will improve their chances for employment and self-sufficiency. However, according to Peeters (2013, p. 558), 'citizen responsibility walks a thin line between freedom and restraint', and it would be a mistake to think that individual responsibility implies that individuals are completely free to take their own course of action (Clarke 2005; Dean 2007; Peeters 2013). The state's expectations on desirable choices and behaviors are framed by a set of norms on what is deemed to be 'reasonable' and 'decent'. But, as Clarke (2005: 451) points out, there is not one 'single coherent underlying moral code, but rather a set of unstable assemblages of what is deemed "reasonable" and "decent" across a variety of sites and practices'. Techniques used in refugee settlement programs are thus often individualized, including individual plans, guidance, and job coaching, often with the explicit goal of 'strengthening the participant' and encouraging them to become active agents of their own lives (Rose 1996; Vesterberg 2013, 2015). However, the essence of these practices is ambiguous. Some techniques might point in the direction of increased 'empowerment' (cf. Brochman \& Hagelund, 2011), placing an emphasis on overcoming the assumed meanings and identifications associated with unemployment or marginalization, while other techniques are directed toward improving the skills thought of as being insufficient in order for migrants to become employable (Vesterberg 2015, p. 307).

\section{Presenting the empirical study}

The themes discussed in this article are part of a larger empirical study looking into practices and outcomes of the Swedish settlement program (Forskningsrådet för hälsa, arbetsliv och välfärd 2014-2017). The results presented here are based on a combination of refugee interviews and content analysis of individual action plans set up by EOs. The two empirical sources and methods of analysis were strategically chosen in order to achieve a holistic understanding of how activation strategies and ideas on responsibility appear in practice in Sweden's settlement policy for refugees. The use of different empirical sources is a way to triangulate the data and the analysis (cf. Patton 1999), thus enabling information from two different types of actors. On the basis of the interviews with refugees and EOs and notes from their fieldwork, this study analyzes how the use of activation is practiced and experienced in refugees' integration process.

\section{Interviews}

Thirty refugees were interviewed in four cities in three different regions in Sweden. The data collection took place between June 2015 and February 2016. EOs and social workers working in the various regions were asked to provide lists of possible interview persons. From the lists provided, we chose to contact both men and women who were either 
near the end of the 2-year settlement period or who had already finished it. This was because we wanted to remove all possible risks that individuals would still be in a dependent position with regards to the authorities. In choosing interviewees, we considered a variation of age and previous working life experiences and educational backgrounds, meaning half of the group of interviewees had a long educational background (upper secondary, academic), and the other half only had the maximum level of compulsory school. Three of the interviewees were illiterate. All of the interviewees had their refugee status approved and had fled war or persecution. Their national backgrounds differed (Iraq, Eritrea, Somali, and Syria), but we did not emphasize their ethnic background analytically because there is no point in attempting to draw generalized conclusions based on ethnicity from such a small sample.

The time that had passed between the beginning and end of the settlement process made it possible for the interviewees to express themselves in Swedish and to look back and reflect on the period. Thus, the reflections in the interviews were made in reference to the present situation as well as in retrospect. We chose 30 interviewees, including 12 men and 18 women.

The interviews took place in different settings chosen by the interviewees, lasted for about 2 hours, and were recorded and printed verbatim. Inviting the interviewees to choose the place for the interview was intentional in order to help them feel comfortable with the environment and to avoid a possible mix up of the interview situation with other meetings involving the authorities (cf. Wikström 2009). Examples of the settings were libraries, cafés, study rooms, and, on occasion, the refugees' homes. In the original study, the themes for the interviews were about the experiences of the 'establishment program', for example, refugees' contact with EOs, whether it was possible for individuals to influence the planning process, and how educational and working-life goals were realized. The interviews also looked into refugees' perceptions of various dimensions in settlement and integration besides that of establishment in the labor market, such as social and health dimensions, that are important for the individual's integration process. Thus, the interviews covered more thematic areas than we used for this article, but two themes were directly concerning this article's purpose - how they experienced the settlement programs' work-oriented activities and how they perceived their interaction with EOs in the planning and realization of the activities.

Informed consent was obtained before and during the interview, and the individuals were informed of the anonymization of their name and the city in which they lived. The same ethical process was practiced for the officials and the local authorities involved. An ethics contract was signed in which we as researchers ensured that we were obliged to follow the same law on secrecy as was undertaken by the PES.

\section{Individual action plans}

The 'action plan' is the main documentation of each refugee's participation in the 2-year settlement program. The plan is an obligatory instrument established at the very beginning of the refugee's settlement program, and the aim is to document and substantiate both the short-term and long-term goals for the refugee's integration process as well as both planned and realized activities (Government bill 2009/10:60). The action plan for each individual normally consists of decisions anchored in legislation, the 
individual's personal information, and assessments of the individual's 'employability' [Sw: arbetsmarknadsbedömning], and it is updated periodically. Part of the action plan consists of email correspondences and notes of meetings taking place with the applicant, the employer, or officials from other authorities.

In the plans we examined, there were dated notes that described the refugees' participation in various programs, training placements, Swedish language courses, and other activities. Some of the plans contained quite long excerpts from e-mail dialogues between employers and EOs as well as notes from physical meetings and dialogues between refugees and EOs. In analyzing the plans, guiding questions were how work strategies were practiced and administered. We had access to personal action plans for 25 individuals from two employment offices in two Swedish cities that had finalized their implementation of the establishment program, and these plans contained a total of 425 pages of text. These plans did not coincide with the individuals chosen for the interviews, but were chosen with the same list of criteria. Names and personal identification numbers in the plans were removed by the officials before we had access to them, and the remaining personal information included age, gender, nationality, and educational and vocational background.

\section{Analysis}

The analysis of both the documents and the interviews was inspired by directed content analysis (Hsiu-Fang \& Shannon 2005). Because this article is focusing on how activation is used as a means in the settlement process and how it is experienced by the refugees, in the first round of the analysis, we asked how activation is practiced, which strategies are used, what their purposes are, how EOs argue for and explain their purpose, and how work strategies are experienced by the refugees. We coded the data and constructed themes based on these questions and findings, and we categorized the themes and predominant images (Marshall \& Rossman 1999). Early on, activation was introduced as a sensitizing concept that we found useful in seeing and organizing the data (cf. Blumer 1954; Bowen 2006). The interviews were read several times by both authors in order to gain a consistent understanding of the text and content. In the second round of analysis, theoretical perspectives were introduced in the analysis process, and responsibilization and conditionalization emerged as guiding concepts to provide a deeper understanding of how activation is practiced and experienced.

\section{Results}

The presentation below sums up and illustrates themes around the work strategy measures adopted in the refugee settlement program from the perspectives of refugees' experiences and officials' practices. The themes extracted from the interviews and from the texts in the personal files together constitute the main findings of the analysis, and the extracts from the interviews and action plans were chosen because they are suitable illustrations to the main findings. Excerpts from plans are anonymized and given pseudonyms, and details about officials and refugees that might reveal their identities have been removed.

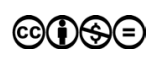




\section{Activation in the refugee settlement program}

When asking what the establishment program is about, a firm 'work focus' emanates from the interviewees' experiences as well as from the texts in the action plans. It seems almost a common understanding that 'work' is the main route to integration and that it is important to be active and to demonstrate activity. As mentioned earlier, the refugee integration policy texts emphasize that the settlement program needs to create incentives for integration into Swedish society with the explicit goal for 'the refugee as quickly as possible to become individually responsible for income through paid labor' (SOU 2008:58, p. 62). At center stage is the design of activities that stress the refugee as a 'worker and contributor', and emphasis is placed on the duties of the refugee to participate and to accept the training placements and jobs that are offered (SFS 2010:197; SOU 2008:58). The strong 'work focus' emphasized in policy texts seems to almost directly correspond to how the spirit of the establishment program is described by interviewees and in action plans. This is manifested in the more or less obligatory participation in 8 hours of activities per day for the refugees and in the direct linkage between the payment of benefits and the demand for partaking in suggested programs. All of the interviewees reflected on the issues of 'being active' and of living up to the explicit expectations on activity, thus to demonstrate activity. A young woman, Ariana, described how she early on understood the necessity to be an 'active' refugee during the settlement period.

Ariana: I had the information [at PES] that the settlement program lasts for two years and that they expect me to be active eight hours per day. That I need to participate in workplace training, Swedish lessons and such - I am obliged to do so.

The Swedish model of refugee settlement, distinguished as a 'rights-based' program, now seems to be a balance between rights and duties. Our data show multiple examples of how EOs put claims on 'activity' as compulsory, but often conveyed with a hazy conception of the individual's 'free choice' of what line to take on the activities that are offered. Selam, in his mid 40s, said:

Selam: My employment officer declared that it is my responsibility to participate all day long in order to have full benefit. He said: "You are free to do what you want, you don't need to go to the Swedish lessons if you're not interested - but then I cannot pay you any money". So what can I do? I have to learn in order to receive 'income'.

The excerpt above illustrates a more or less compulsory activation strategy in practice, but one that is concealed in a promise of self-determination and articulated as the 'individual right' to decide for oneself (cf. Johansson \& Møller 2009; Hobbins 2016). Thus, the work strategy that is practiced is individualized into the individual's responsibility for the governance of active performances. What appear on paper in legal documents and policy texts as refugees' rights to the settlement program and rights to benefits are in practice conditionalized through the linkage made between activity and benefit eligibility (cf. Clarke 2005; Dean 2007; Peeters 2013).

Claims for compulsory participation in the provided activities require control, and the regulation for providing establishment benefits to refugees (SFS 2010:407) is based 
on their full-time participation in activities. Strikingly, much of the content in the action plans was constituted by the frequent documentations of the granting or denial of establishment benefits and notes on the EOs' checking on the refugees' attendance at various activities. Moreover, it is clear that a considerable part of the EO's job is spent on determining whether an absence is legitimate or not, and therefore, the EO needs to check up on the individual refugee's reasons for not showing up at various activities. Below, an excerpt describes an EO's documentation of a male refugee's absence from SFI (Swedish for Immigrants) and the consequences.

EO's e-mail to the SFI teacher: I am aware that Saleh has not been to school for three hours per week since October. Will you forward him a message that he needs to contact me so that we can have a look into this. It is his responsibility. Until he contacts me, his establishment payment will be reduced by three hours per week.

Following up on absences and determining if they are valid or invalid seems to function as a regulating instrument in which the employment officer records the days of absence and makes decisions about reducing the establishment benefit. Work strategies often involve a wide set up of conditionalizing elements, one of which is the obligation to participate in activities in order to receive benefits (cf. Clarke 2005; Dean 2007; Peeters 2013). The controlling of presence also involves a demand on individuals' demonstration of responsibility by keeping the EO informed about one's presence or absence at different activities. If not demonstrated, the EO will interpret the nonvalid absence as irresponsible behavior.

Notes from EO, 11 June 2014: [Saleh] has been absent from the restaurant for three weeks. He says that he has not had the energy to go there. I explained to him that this is not "okay" and that his payment will be reduced. I (again) reminded him and pointed out that it is very important that he shows commitment and shows up on time, otherwise he will ruin all of his possibilities to find a job in the future.

Notes from EO, 8 August 2014: [Saleh] tells me he forgot the meeting yesterday. I explain to him how important it is to show up, to give notice if he must cancel the appointment, to answer the phone, etc., if he is to have a chance to get a job. If Saleh acts this way in a workplace, there is a great risk that he will be fired.

The excerpt above illustrates that the EO uses presence at the workplace as a marker for commitment and that this is, according to the EO, an important personal attribute that one must demonstrate in order to increase one's chances of getting a job (cf. Trnka \& Trundle 2014: 137; Vesterberg 2015). Accountability and responsiveness seem to be of high virtue as a demonstration of responsibility.

As far as we could read from the notes, there were no discussions about why the individual might forget meetings or not show up at the workplace. There seems to be no space for feeling bad or the possibility that individuals might be mistreated at work. The main dimension in the communication is the demonstration of a 'committed worker', which means showing up on time for appointments and for work. 


\section{Responsibilities for employability}

In the beginning of this article, we referred to the gradual change of direction in labormarket policies to more defensive work strategies and the view on unemployment as caused by 'lack of employability' rather than 'lack of employment' (Bengtsson \& Berglund 2012; Garsten \& Johansson 2004; Johansson \& Möller 2009). Related to this is the increase of elements in programs that emphasize the individualization of responsibility in which individuals are encouraged to 'work on themselves' in order to improve their chances in the labor market (cf. Dean 2007; Hobbins 2016; Peeters 2013), often with a disciplining and normative character on the activities provided (Barbier 2014). In our data, we found multiple examples in which the content of activities was directed to improve refugee's job-application skills and language skills and the development of different kinds of social resources thought of as leading to the improvement of the individual's employability (cf. Vesterberg 2013, 2015).

A quite striking example of how refugees need to 'work on their skills' and the view that refugees are expected to bear responsibility for improving their employability is the advice given to several men not only to develop their skills in various ways but also to improve their social network with Swedish locals:

Selam: We are learning how to apply for jobs. We learn how to "log in to the system" at the employment office, how to write applications there, and how to write personal letters. Also how to develop social networks with Swedish people. We learn that you need not be shy, that it is important to go to places where you can meet up with people in different settings.

Also, employers were involved in making claims for different improvements of skills or behaviors of the individuals. In several cases, the exchanges of information concerned the employer's dissatisfaction with a refugee's performance, often in terms of their difficulties in performing according to the employer's expectations or reports about verifiable 'mistakes' and concerns about how they 'fit in at the workplace'. However, what we found was that the claims on 'social skills' were often related to a specific workplace and a particular employer's attitude about 'proper behavior'. The claims on individuals to adjust or improve their behavior could not only be used as arguments for (or a continuation of) a work placement but also for termination of the same.

Below, we find an excerpt from an email sent from an employer to the EO in which the employer argues why a young woman, Roya, no longer is suitable for the workplace.

E-mail from employer to EO: We have had some thoughts about Roya and whether she is suitable to stay with us. At this moment, we don't think we can keep her. /.../ She does not respond correctly to the instructions. I have told her she needs to 'ask for permission', but she takes her own initiatives, but not with good outcomes. /.../ She's not careful when she works, she carries trays with glasses and she puts porcelain wherever she finds an open space instead of asking where the correct spots are./.../ Unfortunately, I think she is the wrong girl for us. Our staff does not want to be responsible for her when it seems like she does not understand our ways or when she shows an inability to respond to instructions. 
The above excerpt illustrates the fluidity in what claims and demands on skills and behaviors are considered reasonable (cf. Clarke 2005). The employer has the power to put forward demands on 'suitable behavior' for the workplace and to use them as an argument for an individual's admittance to the workplace. The causes for terminating Roya's work placement refer not only to the employer's view of Roya's failure to take responsibility but also her failure to demonstrate responsibility in a particular way. We see similarities to what was shown in earlier studies (Vesterberg 2013, 2015) that provided examples of practices used to manage or direct the unemployed into desirable behavior, often with underlying 'silent' assumptions and expectations about 'appropriate' cultural or social behavior. It is also a practice that looks to individuals' lack of employability by linking unemployment to their shortcomings (e.g., Hobbins 2016; Rose 1999). Moreover, the claim from the employer about appropriate behavior is also without any prior questioning forwarded by the EO to Roya, with an underlying requirement for her to adapt to everyday practices and rules in the workplace.

EO's notes from meeting with Roya: I explained to Roya about the information I've received from the restaurant manager, that they experience that she doesn't respect the rules at the workplace, and that they in various and repeated ways have tried to help Roya out, to help her to manage the job tasks. /.../ I emphasized that she has to respect what the staff and manager say about the rules at the workplace.

\section{Work-focused activities for all?}

The focus on activation in the refugee-settlement program is articulated in policy texts with an emphasis on how beneficial it is to 'be active' in comparison to the opposite scenario, to 'be a passive recipient of welfare'. The belief in the powerful force of 'activation', transferred from the area of labor market policy, seems to rest on the idea that refugees will undoubtedly choose living on benefits if they have no activities provided. Activation in our data is used as a means to tackle the 'social risk' of refugees becoming welfare dependent or excluded from the labor market, and it is shown to be practiced through mandatory full-time activity with the assumption that every newly arrived refugee will benefit from 'staying busy'. However, the work-focused activities that are provided differ for individuals, and this was seen in how the interviewees experienced partaking in various activities designed to help prepare for employment. In our data, we noticed a divide in how activities were offered and the experiences of those activities. This divide was between refugees who were having quite frequent contact with officials and who enjoyed workplace trainings and educations of varying kinds, and those who did not even meet the officials for the setting up of a plan, even though this is obligatory to take place within a year after the refugee's permit has been granted. Several men in their mid-40s in a small town, with backgrounds in war zones and with short educational backgrounds and little or no verification of previous employment, had all experienced insufficiency in the support and activities provided during the settlement period. They experienced a stressful situation, feeling pressure to start making a living in order to plan for reunification with their family members, but also experiencing stagnation in the process because they had made very little progress in entering the labor market. Abraham explained that he plodded along with Swedish

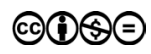


lessons, but after 1 year and 7 months still not had the initial planning meeting with the PES.

Abraham: The employment officer is supposed to on regular notice call us for a meeting. They should - summon us to ask "what do you need, what are your plans", but I have lived here for one year and seven months, but have still not been called for a meeting. Why is that? I've asked many times.

This group of men who had no personal contact with the employment office described how they had 4 hours of lessons in the afternoon, but nothing assigned in the mornings, but were still obliged to fill the demand on full-time activity through what they perceived as 'waiting' at the library for 4 hours a day. Amanine described how he and four of his fellow countrymen experience the waiting at the library as futile and had asked for other activities but were told that no other activities could be offered because of scarce resources.

Amanine: We have to wait here at the library. We just sit here, nothing to do. So, we asked: "Can we not do something else?", but - no - we need to stay here. They [PES] say that we can do our homework or read books.

The above excerpt illustrates a tendency similar to the result of a previous study (Larsson 2015) showing that some refugees are assigned to 'empty activities', activities for the sake of fulfilling the demand on 'active participation'. No matter in what Swedish region we gathered our data, we saw a similar pattern of a tendency to provide activities to individuals judged to be less employable, and these activities were often perceived by the refugees themselves as less meaningful or even as a waste of time. We met several refugees, especially male refugees, who had been recruited to the army at a young age and therefore had short educational backgrounds and no vocational training or confirmed work experiences. We found tendencies to 'park' these individuals in more or less low-quality training placement, and sometimes in activities experienced as 'empty' (cf. Larsson 2015). Selam, a male refugee whose native tongue is Tigrinja, described a work placement with the goal of language training:

Selam: To participate in workplace training is usually a good way to learn about a field of work, to develop your skills in the Swedish language and expand your social network but my placement wasn't that successful.

Interviewer: Why not?

Selam: Well [laughter] it was totally useless! I was at a restaurant and the official said, 'This is a good place for you to practice your Swedish'. But I found that the ones who owned the restaurant and worked there only spoke Kurdish!

In labor market policy's emphasis on activation, there is the inherent assumption 'that everyone has some ability to work and to contribute', and this is conveyed with the belief in the benefits of staying active (cf. Johansson \& Møller 2009; Hobbins 2016). This idea seems to be a guiding principle adopted in the examples from our study, but 
with ambiguous outcomes. Some of our interviewees suggested that the emphasis on full-time activity can, in contrast to the belief in the intrinsic benefit of activity, result in the opposite direction when the individual's capacity or performance is not sufficient. One of our interviewees described how the full-time demand on activity placed on her mother caused feelings of uselessness when she could not benefit from the activities she was assigned to. According to Ariana, her mother was illiterate and suffered from severe stress.

Ariana: Already from the beginning when we had arrived in Sweden she struggled a lot; she was so sad because she lost her husband, my father, and she had to leave all her friends, our house, everything. When she went to Swedish lessons, she was even more run down because she struggled so much to learn to read and write.

Interviewer: But did she really cope with full-time activity?

Ariana: No she did not - that's the point - she felt so bad not to live up to the expectations, not to perform and show results. There was such a pressure laid on her. She felt so bad, but she just HAD TO go to Swedish lessons and workplace training. She kept on saying, 'If I don't go to the activities, we will not have any money'.

Interviewer: But was it not possible for her to be on sick leave if she suffered from anxiety?

Ariana: I guess, but she kept on going, she decided to keep it together. I mean, this is possible for a while, but at the end she was drained of energy, mentally just collapsed, but still continued, because she thought she was obliged to.

The use of individualized work strategies in labor policy and settlement programs walks a thin line between freedom and restraint (cf. Peeters 2013), and the use of activation strategies balances between enabling and pressuring individuals. From studies on forced migration and post-migratory experiences (cf. Lecerof et al. 2015), we learn that a one-sided or unbalanced emphasis on activation laid on a heterogeneous group of refugees with multiple needs, and on those who are stricken with health problems and post-traumatic symptoms, might be counterproductive because not everyone is ready to fully participate socially let alone to perform in work-related activities or education (cf. Slewa-Younan et al. 2015). The pressure on authorities to move the unemployed (refugees) from welfare to work as soon as possible leads to a tension between 'work first' and the provision of responsive and supportive services (Shutes 2011). In contrast to the idea of motivating individuals to take responsibility for their employability through their demonstration of ability to perform and to be 'active', this might lead to marginalizing those with greater needs for assistance (Shutes 2011).

\section{Summarizing discussion}

The aim of this study was to examine how activation in work activities within the Swedish refugee settlement program is practiced and how EOs and refugees articulate and experience the role that activation plays in refugees' integration process. Our 
findings show that activation is a central feature in the settlement program's workoriented activities, which relates to the policies' overarching goal with the refugee settlement process of integration into the labor market (SFS 2010:197). The intention with the changes in refugee integration policy was to shift the focus from 'support' and social responsibility for integration to activation and individual responsibility (Fernandes 2015; Larsson 2015; Qvist 2012). Activation and responsibilization are central parts in the integration process of our interviewees and in the realms of the PES's administration procedures. However, how activation is practiced is mostly related to keeping refugees activated for the sake of increasing employability and for keeping them 'job ready' (Fernandez 2015; Larsson 2015; SFS 2010:197). Moreover, our results on how activation is practiced indicate that in a general sense, activation is used with an emphasis on the idea that it is beneficial for individuals to stay active. In our interpretation, this is in line with a 'workfare ideology' (Peck \& Theodore 2000; Torfing 1999) that seeks to avoid the risks of refugees becoming passive recipients of benefits and the associated risk of refugees becoming 'clientized' and excluded from employment and the ability to provide for themselves. The type of applied activation appearing in our data can be associated with a more disciplining character of labormarket programs (Barbier 2014) influenced by an empowerment ideology in which activation is used as a means to prevent the unemployed (in this case refugees) from being tied up by clientization processes (Barbier 2004; Johansson \& Møller 2004; Peeters 2013; Rose 1996).

Another finding on how activation is practiced is the use of conditionalizing elements, such as demands on full-time presence in planned activities in order to receive benefit payments. The controlling and reporting on presence and absence might put pressure on the individual to remain active, but according to our results, this can also have a negative effect by worsening experiences of stress and incapability (cf. Dingeldey 2007). This result speaks to previous research showing the ambiguous outcomes of conditionalized activation and the discords of conditionality and autonomy that create incentives and empower individuals on the one hand, but on the other hand pressure and force individuals to demonstrate activity (Dean 2007; Handler 2003).

Scholars have pointed out that within labor market policy that emphasizes activation is the inherent assumption that everyone has some ability to work and to contribute (cf. Hobbins 2016; Johansson \& Møller 2009). Our results indicate that the assumption laid on full-time activity might not apply to all individuals and that such a demand on full-time activity might run in opposition to its purpose in some cases. Refugees represent a group that are likely to suffer from post-migratory stress, post-traumatic symptoms, and a load of social stressors, which makes them a group with differing preparedness to participate in activation measures. Moreover, the least employable are provided activities simply for the sake of activation (cf. Bengtsson 2014). These 'empty activities', like waiting at the library, might be viewed as the EO's use of 'adaptive strategies'. This is in accordance with Larsson's (2015) study in which EOs were found to need to come up with strategies in order to meet the current policy's demands for full-time activity. The tendency to 'park' the least employable individuals in empty activities must be questioned. There is a of risk marginalizing those parked in empty activities, and whose need for assistance is greater, if they are not met with the support they need in order to increase their employability (Shutes 2011). From what is shown from our empirical results, the ideas on individualized work strategies' positive influences on individuals 
in terms of 'empowerment', or the boosting effects on individual's motivation and willpower, need a more nuanced outlook.

In the forerunner of the current refugee settlement policy, it was stated that the responsibility for overall integration should be divided among social actors and that local governments had the main responsibility for such work (Government bill 1997/98:16, p. 75). In the present policy, however, it is expected that the refugees themselves take a more active and responsible role in their integration process, while the state takes an interventionist role. We have seen from our results that officials have taken on a monitoring and controlling role in which the main goal is to get refugees to behave according to defined norms. The EOs and employers' demands on behaviors like punctuality, responsiveness, and adaptation to 'workplace culture' thus might be questionable and might represent 'fuzzy' demands that are changeable and adjustable in order to meet labor market needs rather than lead to refugees' improved employability. Moreover, there is a quite evident risk that the use of demands on behavior corrections are ways to put blame on the individual for failure to integrate or for their unemployment (e.g., Hobbins 2016; Mik-Meyer \& Villardsen 2012; Rose 1996).

The meta-theoretical starting point for this article was that ideas about 'work focus' and the application of ideas and practices around 'activation' have travelled from labor market policy (and welfare policy) to the field of refugee integration policy (cf. Czarniawska-Joerges \& Sevón 2005). The strong influences of 'work as the route to integration' and the belief in individualized work strategies undoubtedly permeate the data of our study. Considering that the PES took charge of the refugee settlement program in 2010, the adoption of work strategies does not come as a surprise. Our concluding thoughts are that we find it troublesome that policy practices around activation and employability as the central focus on refugees' integration processes seem almost directly copied from those applied to the unemployed in general. Refugees have unique and complex needs related to post-migratory settlement, rather than simply being unemployed, which implies that individual variations in work readiness need to be better taken into consideration in planning activities and in deciding on which demands on participation are reasonable to make in individual cases.

\section{References}

Barbier, J. C. (2004). Systems of social protection in Europe: two contrasted paths to activation, and maybe a third, Labour and Employment Regulation in Europe, Brussels: PIE-Peter Lang, 233-254.

Bengtsson, M., \& Berglund, T. (2012). Labour market policies in transition: from social engineering to standby-ability. In: B. Larsson, M. Letell, \& H. Thörn (Eds.), Transformations of the Swedish Welfare State. From Social Engineering to Governance? (pp. 86-103). Houndmills, Basingstoke: Palgrave Macmillan.

Bengtsson, M. (2014). Towards standby-ability: Swedish and Danish activation policies in flux, International Journal of Social Welfare 23(S1). doi: http://dx.doi.org/10.1111/ijsw.12075.

Blumer, H. (1954). What is wrong with social theory? American Sociological Review 19(1): 3-10. doi: http://dx.doi.org/10.2307/2088165.

Borevi, K. (2013). Understanding Swedish multiculturalism. In: Kivisto P. and Wahlbeck Ö. (eds) Debating Nordic Multiculturalism in Nordic Welfare States, London: Palgrave MacMillan: 140-169. 
Bowen, G. A. (2006). Grounded theory and sensitizing concepts, International Journal of Qualitative Methods 5(3): 12-23. doi: http://dx.doi.org/10.1177/160940690600500304.

Brekke, J. P., \& Borchgrevink, T. (2007). Talking About Integration. Discourses, Alliances and Theories on Labour Market Integration in Sweden, ISF-report 2007:09, Oslo: Institute for Social Research.

Brochmann, G., \& Hagelund, A. (2011). Migrants in the Scandinavian welfare state, Nordic Journal of Migration Research 1(1): 13-24. doi: https://doi.org/10.2478/v10202-0110003-3.

Czarniawska-Joerges B., \& Sevón, G. (Eds.). (2005). Global Ideas: How Ideas, Objects and Practices Travel in a Global Economy (Vol. 13), Copenhagen: Copenhagen Business School Press.

Clarke, J. (2005). New Labour's citizens: activated, empowered, responsibilized, abandoned? Critical Social Policy 25(4): 447-463. doi: https://doi.org/10.1177/0261018305057024.

Dean, H. (2007). 'The ethics of welfare-to-work', Policy and Politics 35(4): 573-589.

Djuve, A. B., \& Kavli, H. (2007). Integrering i Danmark, Sverige og Norge: Felles utfordringer-like løsninger? Nordisk Ministerråd, København TemaNord 2007: 575.

Djuve, A. B. (2011). Introductory programs for immigrants: liberalism revisited, or changing ideas of citizenship? Nordic Journal of Migration Research 1(3): 113-125. doi: https://doi.org/10.2478/v10202-011-0014-0.

Dingeldey, I. (2007). Between workfare and enablement, European Journal of Political Research 46(6): 823-851. doi: http://dx.doi.org/10.1111/j.1475-6765.2007.00712.

Douglas, M. (1994). Risk and Blame, London: Routledge.

Eastmond, M. (2011). Egalitarian ambitions, constructions of difference: the paradoxes of refugee integration in Sweden, Journal of Ethnic and Migration Studies 37(2): 277-295. doi: https://doi.org/10.1080/1369183X.2010.521323.

Esping-Andersen, G. (1990). Three Worlds of Welfare Capitalism, Cambridge: Polity.

Ericson, R., Barry, D., \& Doyle, A. (2000). The moral hazards of neo-liberalism: lessons from the private insurance industry, Economy and Society 29(4): 532-558.

Fazel, M., Wheeler, J., \& Danesh, J. (2005). Prevalence of serious mental disorder in 7000 refugees resettled in western countries: a systematic review, The Lancet 365(9467): 1309-1314.

Fernandes, A. (2013). Ethnification of new social risks: programs for preparing newly arrived immigrants for (working) life in Sweden, Denmark and Norway. In I. Harsløf \& R. Ulmestig (Eds.), Changing Social Risks and Social Policy Responses in the Nordic Welfare States. Houndmills, UK: Palgrave Macmillan: 189-219.

Fernandes, A. (2015). (Dis)empowering new immigrants and refugees through their participation in introduction programs in Sweden, Denmark, and Norway, Journal of Immigrant \& Refugee Studies, 13(3): 245-264. doi: http://dx.doi.org/10.1080/15562948.20 15.1045054.

Folkpartiet (2004). Utanförskapets Karta. En kartläggning över utanförskapet i Sverige. [The map of exclusion. A mapping of the exclusion processes in Sweden], Stockholm: Folkpartiet.

Folkpartiet (2008). Utanförskapets Karta. Arvet efter Mona Sahlin. [The map of exclusion. the heredity of Mona Sahlin], Stockholm: Folkpartiet.

Garland, D. (2001). The Culture of Control, Oxford: Oxford University Press.

Garsten, C., \& Jacobsson, K. (2004). Learning to be Employable: New Agendas on Work, Responsibility, and Learning in a Globalizing World, Basingstoke: Palgrave Macmillan.

Government bill (1997/98:16). Sverige, framtiden och mångfalden - från invandrarpolitik till integrationspolitik [Sweden, the future and cultural diversity].

Government bill (2009/10:60). Nyanlända invandrares arbetsmarknadsetablering - egenansvar med professionellt stöd. [Newly arrived immigrants' labour market integration individual responsibility with professional guidance]. 
Handler, J. F. (2003). Social citizenship and workfare in the US and Western Europe: from status to contract, Journal of European Social Policy 13(3): 229-243.

Heidenreich, M., \& Aurich-Beerheide, P. (2014). European worlds of inclusive activation: the organisational challenges of coordinated service provision, International Journal of Social Welfare 23(S1): S6-S22.

Hsiu-Fang, H., \& Shannon, S. E. (2005). Three approaches to qualitative content analysis, Qualitative Health Research 15(9): 1277-1288. doi: https://doi.org/10.1177/1049732305276687.

Hobbins, J. (2016). Young long-term unemployed and the individualization of responsibility, Nordic Journal of Working Life Studies, 6(2): 43-59. doi: http://dx.doi.org/10.19154/ njwls.v6i2.4971.

Johansson, H., \& Hornemann Möller, I. (2009). Vad menar vi med aktivering? Stockholm: Liber.

Larsson, J. K. (2015). Integrationen och arbetets marknad: hur jämställdhet, arbete och annat" svenskt" görs av arbetsförmedlare och privata aktörer. [The Market of Integration and Labour, How gender equality, labour and other 'Swedish' phenomena are constructed by employment service officials and private actors], Stockholm: Atlas Akademi.

Lecerof, S. S., Stafström, M., Westerling, R., \& Östergren, P. O. (2015). Does social capital protect mental health among migrants in Sweden? Health Promotion International 31(3): 644-652. doi: https://doi.org/10.1093/heapro/dav048.

Lødemel, I., \& Trickey, H. (2001). A new contract for social assistance. An offer you can't refuse, Workfare in international perspective, Tidskrift: 1-39.

Marshall, C., \& Rossman, G. R. (1999). Designing Qualitative Research, Thousand Oaks: Sage.

Mik-Meyer, N., \& Villardsen, K. (2012). Power and Welfare: Understanding Citizens' Encounters with State Welfare, Routledge.

Newman, I. (2011) Work as a route out of poverty: a critical evaluation of the UK welfare to work policy, Policy Studies 32(2): 91-108.

Patton, M. Q. (1990). Qualitative Evaluation and Research Methods, Newbury Park: Sage Publications.

Peck, J., \& Theodore, N. (2000). 'Work first': workfare and the regulation of contingent labour markets, Cambridge Journal of Economics 24(1): 119-138.

Peeters, R. (2013). Responsibilisation on Government's terms: new welfare and the governance of responsibility and solidarity, Social Policy and Society 12(04): 583-595. doi: https://doi.org/10.1017/S1474746413000018.

Qvist, M. (2012). Styrning av lokala integrationsprogram. [The governance of local integration programmes], (Diss.) Linköping Studies in Arts and Science No. 562, Linköpings universitet.

Regeringsförklaringen (2006). [The declaration of government 2006]. http://www.regeringen.se/informationsmaterial/2006/10/regeringsforklaringen-6-oktober-2006/

Regeringsförklaringen (2014) [The declaration of government 2014]. http://www.regeringen. se/informationsmaterial/2014/10/regeringsforklaringen-3-oktober-2014/

Rose, N. (1996). The death of the social? Refiguring the territory of government, Economy and Society 25(3): 327-356.

SFS (1992:1068). Lag om introduktionsersättning för flyktingar och vissa andra utlänningar. [The law on introduction-benefit for refugees and other foreigners]

SFS (2010:197). Lag om etableringsinsatser för vissa nyanlända invandrare [The law on establishment services for newly arrived immigrants].

SFS (2010:407). Lag om ersättning till visa nyanlända invandrare [The law on financial compensation for newly arrived immigrants].

Shutes, I. (2011). Welfare-to-work and the responsiveness of employment providers to the needs of refugees, Journal of Social Policy 40(3): 557-574. doi: https://doi.org/10.1017/ $\underline{\text { S0047279410000711. }}$ 
Slewa-Younan, S., Mond, J. M., Bussion, E., Melkonian, M., Mohammad, Y., Dover, H., \& Jorm, A. F. (2015). Psychological trauma and help seeking behaviour amongst resettled Iraqi refugees in attending English tuition classes in Australia, International Journal of Mental Health Systems 9(1): 5. doi: https://doi.org/10.1186/1752-4458-9-5.

SOU (2006:79). Integrationens svarta bok. [The 'black' text for integration], Stockholm: Fritzes

SOU (2008:58). Egenansvar med professionellt stöd. [Self-governance with professional support], Stockholm: Fritzes

Forskningsrådet för hälsa, arbetsliv och välfärd [Swedish research council for health, Working Life and Welfare] (2014-2017). Villkorad etablering? Förutsättningar och styrning av unga nyanländas arbetsmarknadsetablering. Dnr. 2013-0299. [Conditional establishment.]

Trnka, S., \& Trundle, C. (2014). Competing responsibilities: moving beyond neoliberal responsibilisation, Anthropological Forum 24(2): 136-153. doi: http://dx.doi.org/10.10 80/00664677.2013.879051.

Torfing, J. (1999). Workfare with welfare: recent reforms of the Danish welfare state, Journal of European Social Policy 9(1): 5-28. doi: https://doi.org/10.1177/095892879900900101.

Vesterberg, V. (2013). Ethnicized un/employability: problematized others and the shaping of advanced liberal subjects, Ephemera 13(4): 737.

Vesterberg, V. (2015). Learning to be Swedish: governing migrants in labour-market projects, Studies in Continuing Education 37(3): 302-316. doi: https://doi.org/10.1080/015 8037X.2015.1043987.

Wiggan, J. (2012). Telling stories of 21st century welfare: the UK Coalition government and the neo-liberal discourse of worklessness and dependency, Critical Social Policy 32(3): 383-405.

Wikström, E. (2009). Etiska dilemman och interkulturell känslighet I kvalitativa forskningsintervjuer, i L Dahlgren \& L Sauer (red.)., Forskning i socialt arbete. Studentlitteratur. Lund. 